\title{
Community Mentoring Through Efforts to Use the Waste of Cow Dung into Biogas and Organic Fertilizer towards Energy Independent Society
}

\author{
Mei Lina Fitri Kumalasari \\ Universitas Islam Negeri Sunan Ampel \\ Surabaya \\ E-mail: meilina_fitri@uinsby.ac.id
}

\author{
Abdul Muhid \\ Universitas Islam Negeri Sunan Ampel \\ Surabaya \\ E-mail: abdulmuhid@uinsby.ac.id
}

\author{
Funsu Andiarna \\ Universitas Islam Negeri Sunan Ampel \\ Surabaya \\ E-mail: funsu_andiarna@uinsby.ac.id
}

\section{Article History:}

Received: 2020-02-06

Revised: 2020-04-15

Accepted: 2020-05-31

Keywords: Cow dung, Biogas,

Fertilizer, Asset Based

Community-Driven Development

\begin{abstract}
The majority of people in Sendang village, the sub-district of Tulungagung Regency are dairy farmers. 90\% of the people have 5-10 dairy cows. A cow can produce approximately $15 \mathrm{~kg}$ of dirt, therefore, five cows can produce $75 \mathrm{~kg}$ of dung per day. During this time cow dung has been utilized as a biogas material, but most cow farmers still throw it into the river. Even the people who already have biogas, they also throw the rest of biogas into rivers eventhough the remaining dirt can be used as manure. This community service was intended to foster public awareness to process cattle dung into biogas and manure so that environmental hygiene is maintained. The approach used was the ABCD (AssetBased Community-driven Development). The result is that the community can make a communal biogas installation independently and utilize the rest of the waste into fertilizer.
\end{abstract}

\section{Introduction}

Animal husbandry is one part of the agricultural sector that has a strategic value in meeting the increasing food needs in Indonesia. One of the livestock sectors that have the potential to be developed and can be a source of economic growth is through dairy agribusiness.

The largest population of dairy cows in Indonesia in 2016 is in East Java with a total of 265,002 cows or $49.63 \%$ of the total population of dairy cows in Indonesia. The largest producer of cow's milk from 2012 to 2016 is also in East Java with an average 
production of 492,460 tons or $53.96 \%$ of national production. ${ }^{1}$ One of the dairy farming business areas in Indonesia is located in the Sendang District, Tulungagung Regency, East Java. According to data from the East Java Livestock Service Office (2018), the number of dairy cows in the Tulungagung Regency in 2017 was 25,355 The largest population of dairy cows is in Sendang District with a total of 12,444 cows. $^{2}$ Research conducted by Larasati in 2014 also stated that the most dairy cow population was in Sendang District with milk production of 51,020 liters per day ${ }^{3}$. Anggreini explained in his 2015 study that Sendang District had many dairy cattle business groups. There are 2,554 active members of dairy farmers. ${ }^{4}$

The results of production from dairy cows that have been commonly used are fresh milk. According to Nurwantoro and Mulyani, milk is the result of fat emulsions in an aqueous solution consisting of sugar, mineral salts, and colloidal proteins. ${ }^{5}$ Dairy cows have a variety of products, including fresh milk as the main product. Besides, dairy cows also produce byproducts, namely cow dung waste. The more cattle population, the higher the waste produced, which will cause complex problems. ${ }^{6}$ Large amounts of livestock waste will cause serious problems. Not only the smell is disturbing, but its presence can pollute the environment, disturb the landscape, and can be a vector of disease ${ }^{7}$. Cattle weighing $454 \mathrm{~kg}$ can produce $30 \mathrm{~kg}$ per day of feces and urine waste. If there are 100 cows in the cattle rancher community, the cow waste produced reaches 3 tons per day and has the potential to disturb the surrounding environment, ${ }^{8}$ and cause negative impacts such as pollution, disease, and air pollution if not managed properly.

Cow's waste air pollution comes from odors caused by the release of ammonia, flying fatty acids, and sulfides in the process of changing impurities. Sulfide is an evil odor gas produced from the sulfate. Cow manure waste also has the potential to be a pathogenic "carrier" that is pathogenic for livestock, plants, and humans. ${ }^{9}$

The issue and focus of this service are to utilize existing natural resources to

\footnotetext{
1 Pusat Data Sistem Informasi Pertanian (PDSIP), Statistik Pertanian (Jakarta: Kementeran Pertanian Republik Indonesia, 2016).

2 Badan Pusat Statistik, Ternak Besar menurut Kecamatan dan Jenisnya di Kabupaten Tulungagung (Tulungagung, 2017).

3 Dian Ayu Larasati, "Faktor yang Berpengaruh Terhadap Produktivitas Susu Sapi Perah Di Desa Geger Kecamatan Sendang Kabupaten Tulungagung," Jurnal Geografi 14, no. 1 (2016).

4 Dewi Angreini, "Program Pendampingan Pencatatan Laporan Keuangan Dan Perhitungan Modal Kerja Bagi Pengusaha Ternak Sapi,” J-ADIMAS (Jurnal Pengabdian kepada Masyarakat 3, no. 1 (2015): 2933.

5 Nurwantoro and Sri Mulyani, Buku Ajar Teknologi Hasil Ternak. Fakultas Peternakan (Semarang: Universitas Diponegoro, 2003).

${ }^{6}$ Amang Fathurrohman, Muh Aniar Hari S, and Moh Awaludin Adam, "Persepsi Peternak Sapi Dalam Pemanfaatan Kotoran Sapi Menjadi Biogas Di Desa Sekarmojo Purwosari Pasuruan," Jurnal Ilmu-Ilmu Peternakan 25, no. 2 (December 7, 2015): 36-42.

7 Suhut Simamora and Salundik, Membuat Biogas Pengganti Bahan Bakar Minyak Dan Gas Dari Kotoran Ternak (Jakarta: Agro Media Pustaka, 2006).

${ }^{8}$ Fathurrohman, S, and Adam, "Persepsi Peternak Sapi Dalam Pemanfaatan Kotoran Sapi Menjadi Biogas Di Desa Sekarmojo Purwosari Pasuruan."

${ }^{9}$ Simamora and Salundik, Membuat Biogas Pengganti Bahan Bakar Minyak Dan Gas Dari Kotoran Ternak.
} 
make it more optimal and efficient to improve the community's economy through an approach that emphasizes the active role of the people of Sendang Subdistrict, Tulungagung, especially the community in Geger Village, in planning, implementing and evaluating research results. As stated earlier there are many cattle, thus it is necessary to use waste so that it does not become pollution.

The community in Geger Village, Sendang Subdistrict was targeted for assistance because the majority of the community were dairy farmers. Almost all houses in Geger Village have their dairy cows. Obtained data in 2016 there were 1,347 cattle breeders. Another reason is that it has not been maximized in processing sewage to damage the environment and health around the area.

The expected condition of assistance is to foster public awareness to process cattle dung into biogas and manure so that environmental hygiene is maintained. Therefore, the service team together with the community planned, implemented and evaluated research programs in improving the economy of dairy farmers in Sendang District, Tulungagung Regency.

\section{Method}

The strategy used in this community service was the ABCD (Asset-Based Community-driven Development) approach. Efforts to assist the community were carried out from the beginning by positioning the assisted community as the main actor to be able to know what strengths they had and to be able to develop their potential and assets to be utilized.

To achieve this, the $\mathrm{ABCD}$ method or technique used is as follows:

\begin{tabular}{|l|}
\hline Asset mapping \\
\hline Preparation of activity program \\
\hline Training program activities \\
\hline Implementation of activities \\
\hline Network strengthening \\
\hline Evaluation \\
\hline
\end{tabular}

This assistance program was carried out in Geger Village, Sendang Tulungagung District. The program is carried out for 3 (three) months, starting in August - October 2019.

Program pendampingan ini dilakukan di Desa Geger Kecamatan Sendang Tulungagung. Pelaksanaan program dilakukan selama 3 (tiga) bulan, dimulai bulan Agustus - Oktober 2019. 


\section{Results of Community Service}

\section{Asset Mapping - Programming Activities}

Identifying the assets, strengths, and potentials of the assisted community in the following ways:

1. Appreciative Inquiry

Appreciative findings Geger village was made by conducting a Group Discussion Forum (FGD) with the community and local stakeholders. In this process, four stages were carried out, namely discovery, dream, design, and destiny. The community service team and community members discussed to share their successes. The community told that $90 \%$ of the population in Geger village had a livelihood as cattle ranchers and had 5-10 cows on average. Some also had 100 cows. There were cows owned by individuals, jointly owned and also cattle owned by investors with a profit-sharing of $50 \%$ each. So far, fresh milk has been taken by Village Unit Cooperatives known as Koperasi Unit Desa (KUD) Tani Wilis or Koperasi Tani is made at the end of the month. The community said that the income from milk production was approximately 3 million-10 million per month.

In an interview, Mrs. Sukarsih said that she has five cows and they produce \pm 48 liters of milk every morning and \pm 25 liters of milk in the afternoon so that each cow produces \pm 14.6 liters of milk each day. This cow's production is greatly influenced by temperature and food sufficiency. Milk production is maximal in cold temperatures. Mrs. Sukarsih lives in Turi hamlet, which is the highest hamlet in Geger Village so that the temperature there is cooler and milk production is optimal. Besides, adequate food must also be considered. One cow requires $\pm 30 \mathrm{~kg}$ of grass for one meal so that in one day requires $60 \mathrm{~kg}$ of grass. Mrs. Sukarsih has five cows so she needs $300 \mathrm{~kg}$ of grass per day. To meet these needs, every cattle rancher also has land to plant grass. In one meter of land, it is capable of producing $15-20 \mathrm{~kg}$ of grass, so that five cows each day need grass from 6 meters of land. ${ }^{10}$

The first harvest of elephant grass can be done after 90 days or three months after planting. Whereas, in the next harvest, elephant grass can be harvested after 40 days in the rainy season and 60 days in the dry season. If the need for elephant grass is not met, cattle farmers must buy it as much as Rp. 25,000 per hassock. One hassock can be used for one cow for one meal. Therefore, for five cows, it spends as much as Rp. 250,000 per day.

A large number of dairy cows in Geger Village also produces a lot of dung. One cow can produce $15 \mathrm{~kg}$ of dung. Five cows will produce $75 \mathrm{~kg}$ of dung in one day. The manure was partly used by some villagers for biogas material which was then used as fuel for gas stoves. Approximately $12 \%$ of the farmers who have dairy cows have used their manure for biogas. However, the amount of cow dung is still

10 Sukarsih, “Jumlah Ternak Sapi dan Perawatannya,” Agustus 2019. 
excessive and thrown into the gutter that flows into the river at the same time as cleaning the dairy cows. Residual waste from biogas that does not change into gas is also discharged by the community into flowing rivers.

The people in Geger Village are very dependent on cow's milk production. To get abundant cow production, it also requires a lot of elephant grass feed. They hope that there will be no shortage of elephant grass so the cattle can produce milk optimally.

2. Community Mapping

The community was divided into five groups based on their hamlets. Each group discussed and mapped the assets in their community. The process of mapping community assets is as shown in Figure 1.
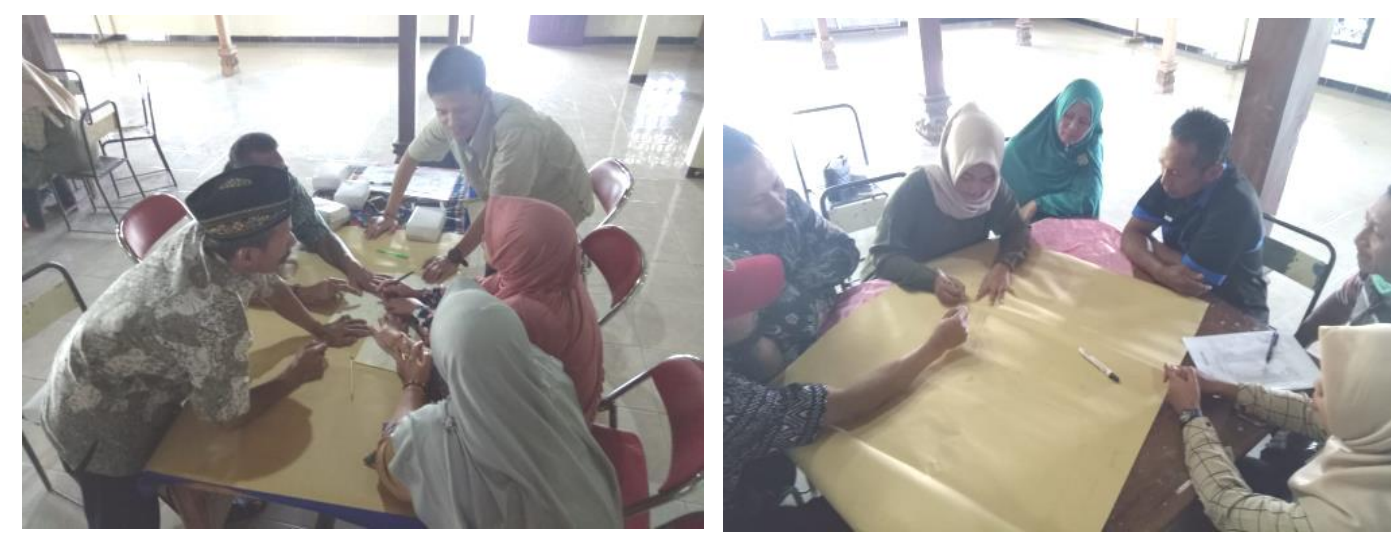

Figure 1. Community Mapping

The results of this community mapping show that Geger village has many assets. These assets include Penampihan Temple, Laweyan Waterfall, Tunjung Biru Education, and Recreation Tourism, coffee plantations, and vegetable and pine gardens. Besides that, there are various religions in Geger Village, including Islam, Christianity, Catholicism, and Hinduism who live side by side with tolerance. Some communities also have household biogas.

\section{Area Search}

After the community made a community map, the community service team together with several communities explored the area that was drawn on the community map. Area search results are presented in Figure 2 below. 


\begin{tabular}{|c|c|c|c|c|}
\hline Zone & River & River-bank & Hills & Highland \\
\hline Land-use & Fount & $\begin{array}{c}\text { Grassland, fount, } \\
\text { field }\end{array}$ & $\begin{array}{c}\text { Houses, green space, } \\
\text { field, grasses, place of } \\
\text { worship, cows } \\
\text { breeding }\end{array}$ & $\begin{array}{c}\text { Houses, green } \\
\text { space, grasses, } \\
\text { temples, cows } \\
\text { breeding }\end{array}$ \\
\hline
\end{tabular}

Figure 2. Area Mapping

4. Mapping Associations and Institutions

The community revealed that organizational activities such as youth organizations could not work because the community was busy taking care of cattle and looking for animal feed. However, in Geger village there is the KUD Tani Wilis and Koperasi Tani which are actively engaged in agriculture and milk distribution to be sent to companies, such as Nestle.

5. Mapping of Individual Assets

Individual assets owned by the people of Geger Village include: (a) Cattle breeders, (b) Farmers, (c) Temple keykeepers, (d) Teachers, (e) cooperation, and (f) Tolerance.

\section{Financial Circulation}

The people of Geger Village have the main livelihood as cattle farmers. Their main income is from selling cow's milk. Milk from milking is taken by KUD Tani Wilis and Koperasi Tani every morning and evening. Dairy milk is weighed on the spot and payment is made at the end of the month. The community can also borrow money or buy goods at the KUD Tani Wilis and Koperasi Tani with a payment system deducted from monthly income. The money earned is used for raising cattle and daily necessities. Besides, some people sell cows milk around in the morning and some also sell vegetables from their agriculture. Whereas, the village activities are carried out using budget funds from the government and village savings.

7. Priority Scale

Assets owned by villages and individuals are discussed to look for priorities. From the results of the discussion, it was determined that the main assets that have not been utilized are the results of cattle farms in the form of cow dung.

8. Compilation of Activities Programs

After the community was able to find assets that could be developed in their 
area, the community was invited to dream to develop and achieve their dreams with the assets they had. For this reason, a program was carried out by involving the community directly. It was intended that the community also played an active role in the development of assets and can be continuous. The community agreed to make a communal biogas installation that has a final shelter. The remaining dirt in the final shelter can be used directly as manure. To realize this, a working group was formed to make communal biogas assisted by experts.

\section{Implementation of Activities}

The working group constructed a communal biogas installation independently, assisted by experts in the production of communal biogas. The biogas installation is connected to the final shelter which will hold the remaining dirt so that it can be directly used as manure. Besides that, a connecting pipe was also made from the final disposal site to the yard so that the rest of the liquid waste can directly flow into the plot which ultimately helps fertilize the vegetable plants or elephant grass.

\section{Network Strengthening}

Network strengthening activities involved all relevant stakeholders. The purpose of this activity was to realize the cattle breeder network media so that the cattle breeder community network could be stronger. The stakeholders in the assistance program were community leaders such as the village head and village secretary. Also, it involved people from KUD Tani Wilis as experts to assist in the production of communal biogas independently and community cadres set up independent communal biogas installations.

\section{Evaluation}

Evaluation needs to be done in each activity program to see whether the program runs well so that the people of Geger Village can be said to be independent. In conducting the evaluation, the assisting team worked closely with the local community to conduct monitoring.

The parties involved in the assistance program were community leaders, such as the village head and village secretary. In addition, it involves people from KUD Tani Wilis as experts to assist in the production of communal biogas independently and community cadres set up independent communal biogas installations.

\section{Results and Discussion}

Geger Village is one of the villages in Sendang Subdistrict and is the westernmost of the 11 other villages. The northern boundary of Geger Village is bordered by Ponorogo Regency. In the south it borders Kedoyo Village, in the west, it borders Gambiran Village, Kec. Pagerwojo and the east are directly adjacent to Nglurup Village. 
The distance from Geger Village to the capital of Sendang District is $5 \mathrm{Km}$, and the distance from Geger Village to the capital of the Tulungagung Regency is $30 \mathrm{Km}$ with \pm 1 hour. Geger Village is located on the slopes of Gunung Wilis and has an area of 1,609.8 hectares and is inhabited by 4,468 people, consisting of 2,233 male residents and 2,235 female residents. In this village, 1,208 households occupy 5 hamlets, 20 RW, and 27 RT. The five hamlets are Tumpakpring, Sukorejo, Tambibendo, Ngrejeng, and Turi.

The average daily temperature in Geger Village is $230 \mathrm{C}$ and has an altitude of 600-1,025 meters above sea level. This village has a rainfall climate ranging from 2,611 $\mathrm{mm} / \mathrm{yr}$. The biggest livelihood in Geger Village is dairy farmers. $90 \%$ of the population has dairy cows with an average of 5-10 cows per house.

The village community cooperates with KUD Tani Wilis and Koperasi Tani in marketing their milk. Community activities are always the same every day. People cleaned their pens and dairy cows from 05.00 in the morning. They then squeezed cow's milk from 06.00 and at 06.30 in the morning the KUD Tani Wilis or Koperasi Tani had come to collect milk. The community then looked for elephant grass for an animal feed until noon. Next, they repeated morning activities in the afternoon to milk. The community started cleaning the cages and dairy cows at 15.00 and started milking the cows at 15.30 in the afternoon. KUD Tani Wilis or Koperasi Tani came to collect milk at 16.30. Dairy milk was weighed on the spot and payment was made at the end of the month.

Numerous dairy cows in Geger village produce a lot of dung too. The manure was partly used by some villagers for biogas material which was then used as fuel for gas stoves. As many as $\pm 12 \%$ of the people who have dairy cows have used their manure to become biogas. But the amount of cow dung is still excessive and thrown into the gutter that flows into the river at the same time as cleaning the dairy cows. Residual waste from biogas that does not change into gas is also discharged by the community into flowing rivers.

The community service team asked permission to the Head of Geger Village on August 2, 2019, by explaining the purpose and objectives of the program. The team also asked the village head for help to invite the community to discuss together. Prior to the discussion, the team traveled around Geger Village for two days on August 3-4, 2019 to see the environmental conditions and assets or potential in the village. The team also chatted with local people to dig up information.

The idea of change from bottom-up is very important in community development. This idea is realized by respecting knowledge, skills, local culture, local resources, and local processes. The bottom-up approach is also carried out by looking for the interests, talents, willingness, and potential of the people of Geger Village. Thus, the empowerment was carried out and started from what they have and what is in 
themselves as a potential and an asset that must be developed. ${ }^{11}$ This method is also known as the ABCD (Asset-Based Community-driven Development) method.12

The community service activities were carried out by discussing with the community and community leaders through forum group discussion (FGD), which was finally held on August 24, 2019. This activity was carried out to look for assets and determine priority assets that could be increased. Priority assets in Geger village that had not been utilized were products from cattle farms in the form of dung. The day after the FGD on August 25, 2019, the team conducted a search of the area accompanied by a working group that had been formed. The dedication team looked at assets in more detail.

This cow dung if left untreated will harm society, such as environmental and air pollution, and has the potential to become a carrier for various parasitic pathogens for livestock, plants, and humans. ${ }^{13}$ The community service team and the people gathered again on 31 August 2019 to plan the program. The discussion concluded that they would make communal biogas for three to four houses and a working group was formed to make communal biogas as a pilot product.

According to Ibrahim, one way to overcome the problem of cow manure waste pollution is by processing it into biogas fuel. The raw material for biogas energy is nonfossil fuel, which contains organic materials such as livestock resources. ${ }^{14}$ Biogas adalah gas yang dihasilkan oleh aktivitas mikroba secara anaerobik pada bahan-bahan organik seperti kotoran hewan yang biodegradable. Biogas is a gas produced by anaerobic microbial activity in organic materials such as biodegradable animal waste. Biogas produced by anaerobic activity is used in biodegradable waste treatment because it can produce fuel and destroy pathogenic bacteria and reduce the volume of waste. The main content of biogas consists of 55-75\% methane and 22-45\% CO2. Methane in biogas is relatively cleaner in combustion than coal and produces greater energy with less carbon dioxide emissions. ${ }^{15}$

The remaining substance of the digesterization process in making biogas can be used as manure that is ready for sale or can be used to fertilize elephant grass as their cattle feed. ${ }^{16}$ Therefore, the rest of the cow dung in the final shelter can be directly utilized by the community as manure.

11 Jim and Frank Tesoriero, Community Development : Alternative Pengembangan Masyarakat Di Era Globalisasi (Yogyakarta: Pustaka Pelajar, 2008).

12 N Salahudin, Panduan KKN ABCD (Asset Based Community-Driven Development) UIN Sunan Ampel Surabaya (Surabaya: LP2M UIN Sunan Ampel Surabaya, 2015).

13 Salundik, "Aplikasi Flexible Tank Dari Karet Sebagai Penampung Biogas Portable" (Bogor: IPB Scientific Repository, 2009).

14 Ibrahim Ibrahim, Mardjoko Idris, and Bachrum Bunyamin, "Peningkatan Kesejahteraan Masyarakat Desa Tertinggal Melalui Biogas Kotoran Sapi," Jurnal Bakti Saintek: Jurnal Pengabdian Masyarakat Bidang Sains dan Teknologi 1, no. 1 (April 7, 2017): 33.

15 Z Zhang, "Impact of Pretreatment on Solid State Anaerobic Digestion of Yard Waste for Biogas Production," World J Microbiol Biotechnol 30, no. 2 (2014).

16 Saputri and Fajar Yasinta, "Pemanfaatan Kotoran Sapi Sebagai Bahan Bakar Biogas," Jurnal Penelitian sebagai Bahan Bakar PLT 80 KW 1 (2014). 
Communal biogas was conducted in Turi Hamlet which is the top hamlet in Geger Village. On September 1, 2019, coordination was made between the team and the working group for the implementation of the work program. The service team brought in a team of experts making communal biogas that taught the working group to make biogas correctly. The process of making biogas lasted for three weeks from 7 to 29 September 2019. The first week was digging digesters with a depth of $10 \mathrm{~m}$. The excavation needed a relatively long time because the land in Turi was clay which was difficult to extract, and the digging activity coincided with the commemoration of the independence of the Republic of Indonesia, so the people had to spare their time.

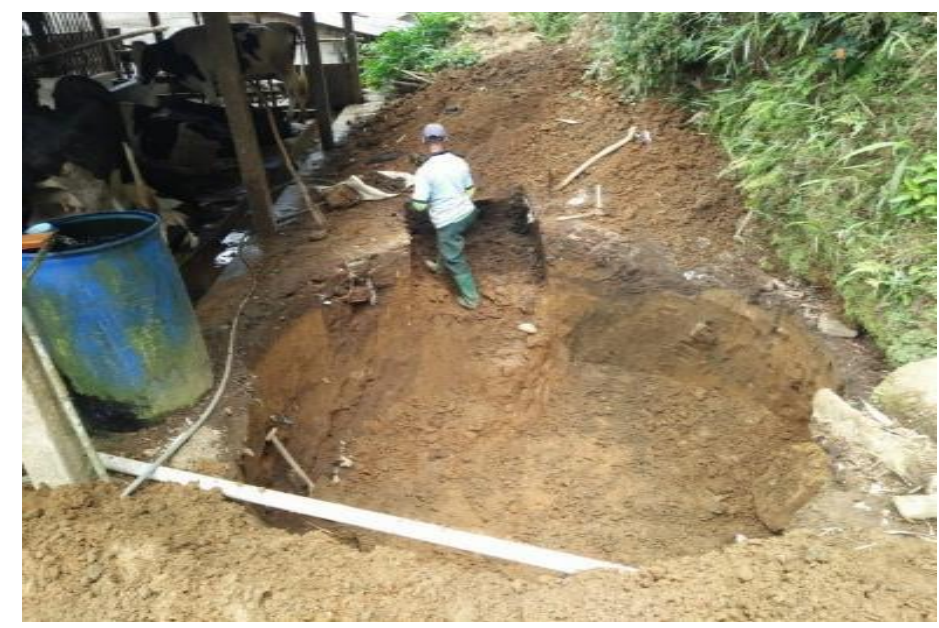

Figure 2. The digging process of the digester

After the working group dug a $10 \mathrm{~m}$ deep digester, a foundation was made with bricks and then cast with cement covered. After that, a place was made for the storage of methane gas and the final reservoir for the remaining dirt that is connected to the pipes and faucets installed to open and close the gas flow.

Prepared communal biogas with a mixer/dung mixer and a landfill is used to process cow dung into gas fuel and manure. Communal biogas was formed on September 19, 2019. Cow dung was put in a mixer with a ratio of cow dung: water was 1:1.5. After that cow dung which was put into the digester was deposited for \pm 30 days so that the methane gas formed could be optimally used as fuel for gas stoves. Gas in this communal biogas can be used on November 10, 2019.

The final disposal site is connected by pipes that lead to the yard. The rest of this liquid cow dung can directly flow into plants and become manure. Besides, the remaining cow dung which is still in the landfill can be taken directly to be used as manure on agricultural land far from home. The pipe in the upper channel of the gas reservoir is connected to the gas stove. If the people are going to use this gas, they just need to turn the tap to open the gas flow. On the stove mounted manometer or pressure meter which is useful for monitoring gas pressure. 



Figure 4. (A) Digester Casting; (B) Methane Gas Reservoir Installed by Faucet; (C) Making Cow Final Manure Shelter;

(D) Communal Biogas with Final Disposal Sites

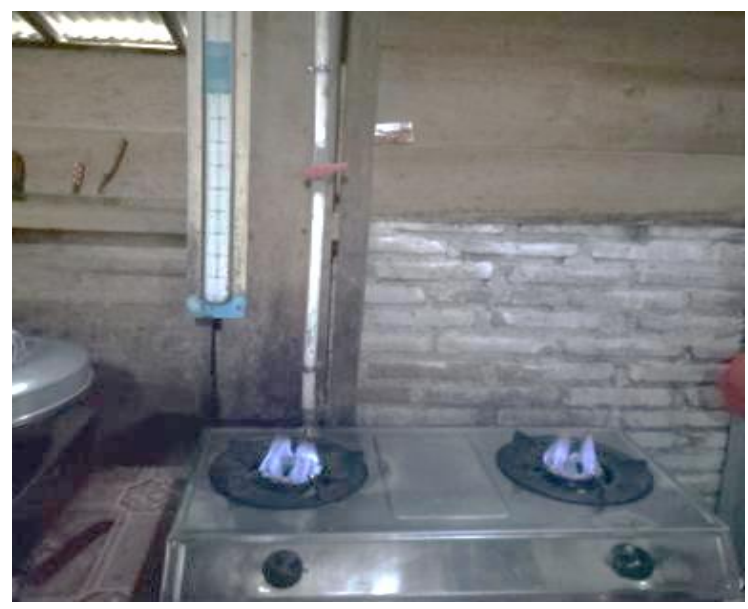

Figure 5. The stove with biogas from cow dung

After all the mentoring processes were completed, the team and the working group put up an information board for the communal biogas assistance program as a result of collaboration from the Faculty of Psychology and Health of UIN Sunan Ampel Surabaya, the Ministry of Religion of the Republic of Indonesia and the Geger Village local government. With the installation of this information board, it is hoped that other 
citizens can see and are interested in participating in making communal biogas independently.

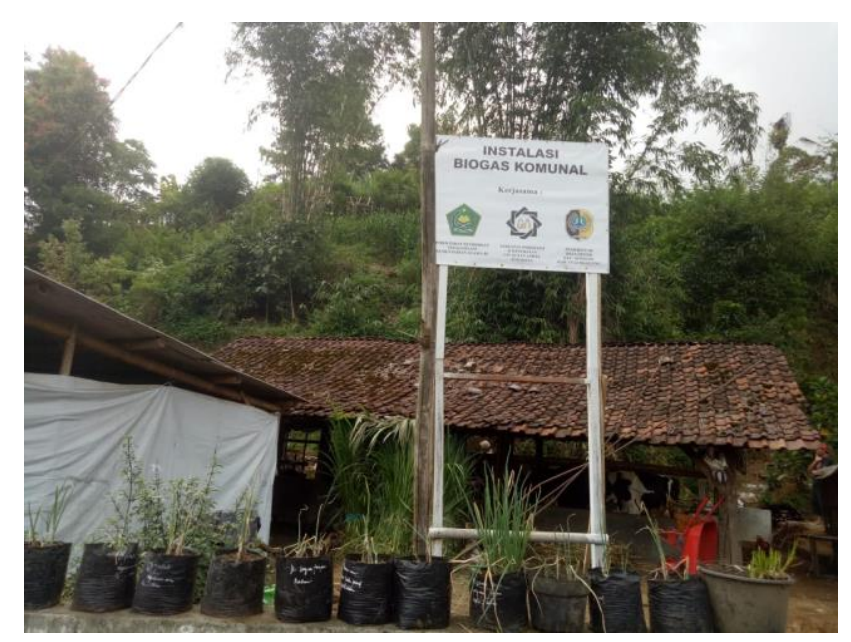

Figure 6. Communal biogas installation information board

\section{Conclusion}

The people in Geger Village can set up communal biogas and utilize the remaining cow dung into manure independently. They have reduced their activities to dump cow dung into the river and drain the remaining dung to the final disposal site. The remaining cow dung in the final shelter is used as manure so that agricultural products and animal feed can flourish. In addition, household expenditure for purchasing liquid petroleum gas (LPG) gas has also been reduced.

Based on the results achieved, it is expected that the community can utilize the results of biogas and cow manure residue into manure optimally and can provide training to other people to make communal biogas installations in other hamlets. Also, it is hoped that the community will be more concerned about the environment and nobody will dump cow dung into the river any longer.

\section{Daftar Referensi}

Angreini, Dewi. "Program Pendampingan Pencatatan Laporan Keuangan Dan Perhitungan Modal Kerja Bagi Pengusaha Ternak Sapi." J-ADIMAS (Jurnal Pengabdian kepada Masyarakat 3, no. 1 (2015): 29-33.

Badan Pusat Statistik. Ternak Besar menurut Kecamatan dan Jenisnya di Kabupaten Tulungagung. Tulungagung, 2017.

Fathurrohman, Amang, Muh Aniar Hari S, and Moh Awaludin Adam. "Persepsi Peternak Sapi Dalam Pemanfaatan Kotoran Sapi Menjadi Biogas Di Desa Sekarmojo Purwosari Pasuruan." Jurnal Ilmu-Ilmu Peternakan 25, no. 2 (December 7, 2015): $36-42$. 
Ibrahim, Ibrahim, Mardjoko Idris, and Bachrum Bunyamin. "Peningkatan Kesejahteraan Masyarakat Desa Tertinggal Melalui Biogas Kotoran Sapi.” Jurnal Bakti Saintek: Jurnal Pengabdian Masyarakat Bidang Sains dan Teknologi 1, no. 1 (April 7, 2017): 33.

Jim, and Frank Tesoriero. Community Development: Alternative Pengembangan Masyarakat Di Era Globalisasi. Yogyakarta: Pustaka Pelajar, 2008.

Larasati, Dian Ayu. "Faktor yang Berpengaruh Terhadap Produktivitas Susu Sapi Perah Di Desa Geger Kecamatan Sendang Kabupaten Tulungagung." Jurnal Geografi 14, no. 1 (2016).

Nurwantoro, and Sri Mulyani. Buku Ajar Teknologi Hasil Ternak. Fakultas Peternakan. Semarang: Universitas Diponegoro, 2003.

Pusat Data Sistem Informasi Pertanian (PDSIP). Statistik Pertanian. Jakarta: Kementeran Pertanian Republik Indonesia, 2016.

Salahudin, N. Panduan KKN ABCD (Asset Based Community-Driven Development) UIN Sunan Ampel Surabaya. Surabaya: LP2M UIN Sunan Ampel Surabaya, 2015.

Salundik. "Aplikasi Flexible Tank Dari Karet Sebagai Penampung Biogas Portable." Bogor: IPB Scientific Repository, 2009.

Saputri, and Fajar Yasinta. "Pemanfaatan Kotoran Sapi Sebagai Bahan Bakar Biogas." Jurnal Penelitian sebagai Bahan Bakar PLT 80 KW 1 (2014).

Simamora, Suhut, and Salundik. Membuat Biogas Pengganti Bahan Bakar Minyak Dan Gas Dari Kotoran Ternak. Jakarta: Agro Media Pustaka, 2006.

Sukarsih. "Jumlah Ternak Sapi Dan Perawatannya," Agustus 2019.

Zhang, Z. "Impact of Pretreatment on Solid State Anaerobic Digestion of Yard Waste for Biogas Production." World J Microbiol Biotechnol 30, no. 2 (2014). 